\title{
AFRICA REVIEW \\ AN UP-TO-DATE GEOGRAPHICAL, HISTORICAL, POLITICAL AND ECONOMIC SUMMARY OF THE AFRICAN COUNTRIES
}

Prepared by: $\quad$ F. Pauwels, P. Van Damme, D. Theeten, Chr. De Keyser, S. Hoste, P. Wymeersch ${ }^{+}$

\section{MAURITANIA}

1. Official name: Islamic republic of Mauritania

al-Jumhuriya al-Muslimiya al-Mawritaniya

2. Geography:

2.1. Situation: onthe west coast of Africa and comprising the western part of the Sahara desert. Between $15^{\circ} \mathrm{N}$ and $27^{\circ} \mathrm{N}, 23^{\circ} \mathrm{W}$ and $5^{\circ} \mathrm{W}$.

2.2. Total area: $1030700 \mathrm{~km}^{2}$.

2.3. Natural regions: the major part of the country is desert. Only a narrow zone in the south has an annual rainfall of more than $200 \mathrm{~mm}$ and has a sudanese savanna type vegetation. The relief is mostly flat with a coastal plain below $50 \mathrm{~m}$, interior plains about $200-250 \mathrm{~m}$, while inselbergs have the highest elevations, up to $915 \mathrm{~m}$. 


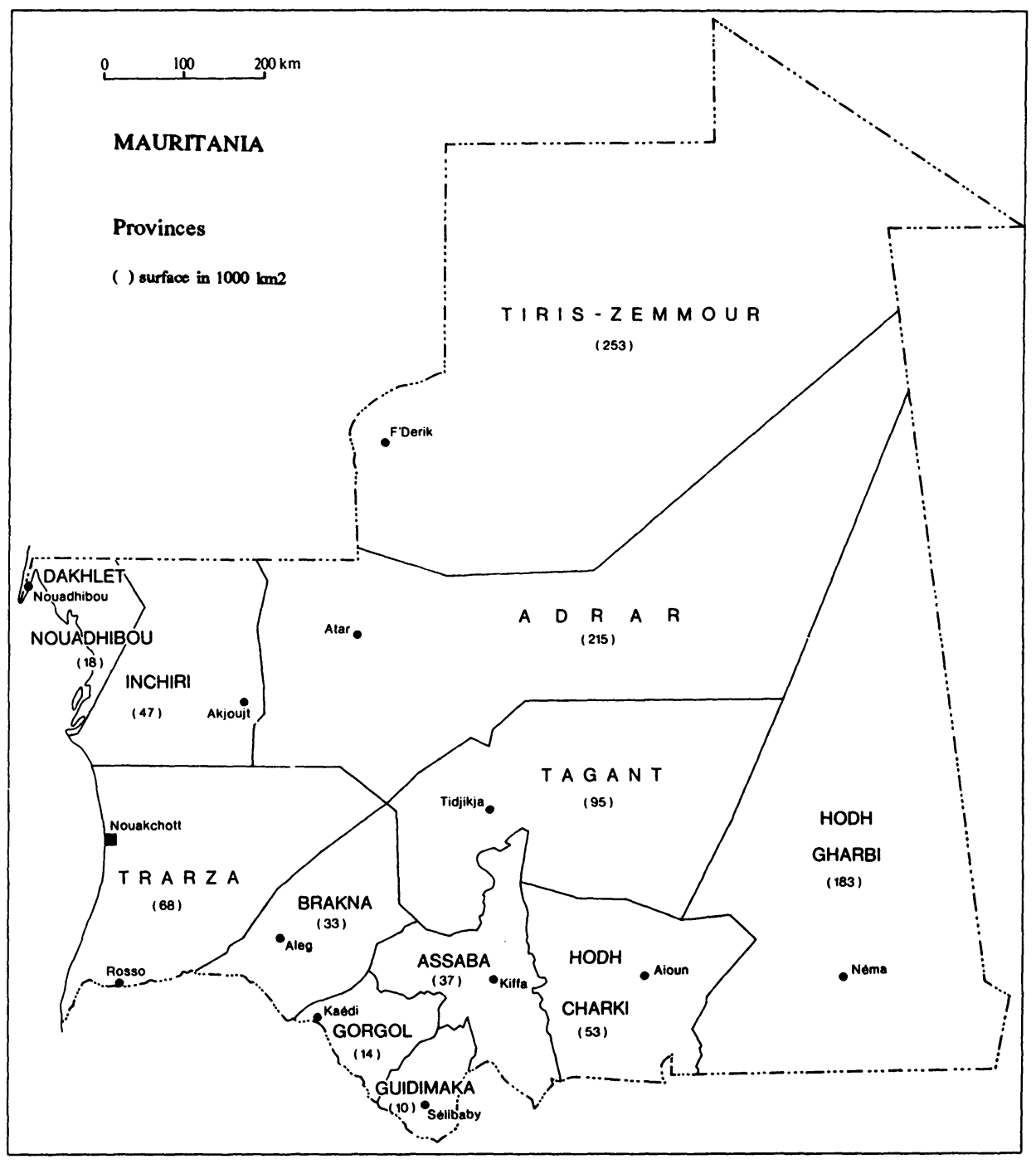


2.4. Climate: tropical arid. The northeasterly trade winds and the easterly Harmattan blow during the winter and are responsible for the aridity. The northern monsoon blowing in the summer, brings some precipitation.

3. Population:

3.1. Total population: $1.7 \mathrm{mln}$ (1985), urban population: $31 \%$.

3.2. Population density: 1.6 per $\mathrm{km}^{2}$.

3.3. Population growth rate: $2.1 \%$ (1980-1985).

3.4.Capital: NOUAKCHOTT, 150000 inh. (1980).

3.5.Languages: Arabic, French (official), Hassania.

3.6. Religion:Islam.

4. History:

The original population of Mauritania was black but, since the 3rd century, Berbers and since the 8th century, Arabs invaded the country. When the first European traders settled down around 1638, the succession of different kingdoms and empires was ended with almost total dominance by the Arabs. In 1903 Mauritania became a French protectorate, in 1920 a colony of France, in 1946 a French Overseas Territory and since 1960 Mauritania is an independent republic.

5. Nature of political system:

The President heads the 14-member Military Committee for National Salvation.

6. Economy:

GDP:agriculture:29\%, industry: 25\%, services: $47 \%$ (1985). Employment: agriculture: $69 \%$, industry: $9 \%$, services: $22 \%$ (1980).

6.1.Mining: 
Second iron producer of Africa (8-10 mln t/year). Other minerals are copper, salt, gypsum and titanium.

\subsection{Agriculture:}

Less than $1 \%$ of the total area is arable land or cultivated with permanent crops (1984). The sedentary rural population represents about $15 \%$ and nomads $77 \%$ of the total population. Most farming is practised in the south, where annual rainfall is more than $450 \mathrm{~mm}$ or, on the lower interfluves and slopes of the valleys (Senegal and seasonal rivers), which are flooded each year, or in the wadis or adjacent to dams. The farmers are mostly black, Tekrour or Soninké, and the main foodcrops are millet and sorghum, also maize and cowpeas. In the oases, the date palm is typical, while besides the staple food aforementioned also wheat, barley, green vegetables and tobacco are produced with the use of fertilization and irrigation.

\subsection{Livestock:}

$38 \%$ of the total area is permanent pasture (1984). In the desert area pastoral economy is predominantly nomadic and even the sedentary farmers of the south have considerable herds. Milk is an important item and some meat is consumed domestically or exported. Animal husbandry occupies some three quarters of the population. However, herds are regarded as possessions of status and prestige value rather then assets for economic production. Nomadic migration is widespread. The northern zone is essentially camel country with goats and sheep as well. In the sahelian zone, where water is available in relative abundance cattle are the chief stock, along with sheep,goats, donkeys and horses. Humped cattle of the Mause Zebu type are predominant.

\subsection{Forestry and woodland:}

$15 \%$ of the total area (1984). Real forests are rare. It is only formed in the Senegal valley it is largely composed of Acacia scorpioides (gomakier) and in the wadis of Hyphaene thebarca (dum palm) and Acacia nilotica (amours). Woodland savanna is more extensive. The wooded steppe provides tree and shrub grazing for camels and goats. Dense stands of Acacia senegal are exploited for gum.

\subsection{Fishery:}


200-nautical-mile limit declared in 1980. Potential catch estimated up to $1 \mathrm{mln} \mathrm{t} / \mathrm{year}$. Very small percentage of catch has been landed by Mauritanian boats.

\subsection{Industry:}

Poorly developed, no food processing apart from fish-drying and canning.

6.7. Weights, measures and currency:

$\mathrm{kg}$, meter

1 Ouguiya (Oug) $=5$ khoums

1 US $\$=67.16$ Oug (Nov. 1984)

7. Trade:

Total exports amount to $374 \mathrm{mln}$ US \$ (1985), mostly iron ore, copper, fish, livestock, salt and gum arabic. Main clients are the EEC, Japan and Zaïre.

Total imports amount to $234 \mathrm{mln}$ US \$ (1985). Main suppliers are the EEC, the USA, Senegal and China.

8. Miscellaneous:

Literacy: $15 \%$.

World Bank classification: Mauritania belongs to the lower middle-income economies with a GDP per capita of 420 US \$ (1985).

Membership of international organisations:

GATT, ILO, IMF, UN, UNESCO, WHO, African Development Bank, Arab Common Market, Arab Fund for Economic and Social Development, Arab League, Islamic Conference, Islamic Development Bank, World Bank.

Mauritania is a signatory to the Lomé Convention (EEC-ACP).

Embassy of Mauritania in Belgium: P. Lautersstraat 1

1050 Brussel

Tel. 02/640.76.75

Belgian Embassy for Mauritania: Route de la Corniche Est

P.O. Box 524

Dakar, Senegal 